\title{
HYDRO-ABRASIVE RESISTANCE AND MECHANICAL PROPERTIES OF CONCRETE WITH ADDED FLY ASH
}

\author{
Nenad Ristić \\ University of Niš, Faculty of Civil Engineering and Architecture, Serbia, Ph.D. \\ Corresponding author: nenad.ristic@gaf.ni.ac.rs, nenadristic82@gmail.com \\ Zoran Grdić \\ University of Niš, Faculty of Civil Engineering and Architecture, Serbia, Full Professor \\ Gordana Topličić-Ćurčić \\ University of Niš, Faculty of Civil Engineering and Architecture, Serbia, Associate Professor
}

\begin{abstract}
The durability of hydraulic engineering structures mostly depends on the resistance of their concrete surfaces to mechanical abrasion. In this paper, we study the hydro-abrasive resistance and mechanical properties of concrete in which cement is partially replaced with fly ash in various proportions. To evaluate these concretes, we measured their compressive strength, flexural strength, static modulus of elasticity, ultrasound velocity through concrete, and sclerometer rebound. The hydro-abrasive resistance of concrete with $15 \%$ fly ash was similar to that of reference concrete without fly ash. However, concretes with more than $15 \%$ fly ash exhibited lower resistance to abrasive erosion than the reference concrete. Also, the mechanical properties of the concrete deteriorated as the fly ash content increased.
\end{abstract}

Keywords: fly ash, concrete, hydro-abrasive resistance, mechanical properties

\section{HIDROABRAZIVNA OTPORNOST I MEHANIČKE KARAKTERISTIKE BETONA S ELEKTROFILTERSKIM PEPELOM}

Sažetak: Trajnost hidrotehničkih inženjerskih objekata u najvećoj mjeri zavisi od otpornosti površine betona prema mehaničkom habanju. U ovome radu prikazana je hidroabrazivna otpornost i mehaničke karakteristike betona u kojima je cement djelimično zamijenjen elektrofilterskim pepelom u različitim omjerima. Za procjenu ovih betona mjerena je čvrstoća pri pritisku, čvrstoća pri savijanju, statički modul elastičnosti, brzina ultrazvuka kroz beton i odskok sklerometra. Hidroabrazivna otpornost betona s $15 \%$ elektrofilterskog pepela bila je slična otpornosti etalon betona bez dodatka elektrofilterskog pepela. Međutim, betoni s više od $15 \%$ elektrofilterskog pepela pokazuju manju otpornost prema abrazivnoj eroziji u odnosu na etalon beton. Također, mehaničke karakteristike betona su se pogoršale s povećanjem sadržaja elektrofilterskog pepela.

Ključne riječi: elektrofilterski pepeo, beton, hidroabrazivna otpornost, mehaničke karakteristike 


\section{INTRODUCTION}

The history of building materials has shown that builders used hydraulic binders of volcanic ash: natural materials characteristic of the prominent pozzolanic activity. Two thousand years ago, it was found how to replace natural volcanic ash with artificial ash [1]. Of the artificial ashes produced by combustion of solid fuels, the most prominent is fly ash, which is extracted by electrostatic precipitators from exhaust gases in thermal power plants by firing coal dust in energy boilers [2].

In hydraulic structures, abrasive wear of concrete is most often caused by water-borne particles (such as silt, sand, and gravel) rolling and eroding the surface during hydraulic processes. Abrasive-erosive concrete damage is a continuing issue in maintaining hydraulic structures and must be accounted for when designing structures and choosing concrete mixtures. This process can cause damage on the order of several centimeters, but in some cases it can cause much greater damage after only several years of abrasive action. Weak abrasiveerosive action is not a major problem, but very pronounced action can endanger the concrete's structural integrity as well as the structure's functionality [3]. Abrasive-erosive protection of hydraulic structures made of concrete requires durable concrete mixtures resistant to abrasion-erosion.

Some researchers have studied the influence of Class $\mathrm{F}$ fly ash on the abrasion resistance of concrete. For example, Liu [4] reported that $36 \mathrm{~h}$ of abrasion testing produced similar abrasion in a reference concrete without fly ash and a concrete with $25 \%$ fly ash. However, after $72 \mathrm{~h}$ of testing, the concrete with fly ash had suffered about $25 \%$ more abrasion than the reference concrete. Concrete containing Class $\mathrm{C}$ fly ash exhibited better abrasion resistance than both concrete without fly ash and concretes containing Class $F$ fly ash [5]. Fly ash concrete appears to have similar abrasion resistance to normal concrete [6].

Dhir et al. [7] concluded that near-surface characteristics of concrete such as absorption, intrinsic permeability, and vapor diffusivity are closely related with its abrasion resistance. Siddique [8] investigated how replacing cement with 0-40\% Class $\mathrm{F}$ fly ash in concrete affected its abrasion resistance at ages up to 365 days. The abrasion resistance increased as the fly ash content increased, but at high levels $(50 \%)$ it decreased the abrasion resistance at all ages compared to concrete made without fly ash. Similarly, superplasticized concrete with high volumes (55-66\%) of Class $\mathrm{F}$ fly ash had poorer abrasion resistance than concrete without fly ash [9].

Yazici and Inan [10] developed a relationship between the mechanical properties (compressive and splitting tensile strengths) and abrasion resistance of high-strength concretes (HSCs) with compressive strengths of 65$85 \mathrm{MPa}$. They concluded that the abrasion resistance of HSCs can be estimated from the compressive and splitting tensile strengths: concretes with high compressive and splitting tensile strengths have high abrasion resistance. Finally, Siddique and Khatib [11] investigated the abrasion resistance and mechanical properties of concrete with high volumes of fly ash. In the present work, we added fly ash from the Kostolac thermal power plant to hydraulic concrete structures, hoping to reduce the amount of ash waste and studying how adding this fly ash affected the concrete's mechanical characteristics and hydro-abrasive resistance.

\section{EXPERIMENTAL}

The reference concrete was produced with Portland cement (CEM I $42.5 \mathrm{R}$ ), whose physical and mechanical characteristics are given in Table 1. The aggregate used to prepare this concrete was a mixture of three fractions $(0 / 4,4 / 8$, and $8 / 16 \mathrm{~mm})$ from the river aggregate of the Southern Morava River. Figure 1 shows the particle-size distributions of these fractions. Table 2 gives the chemical composition of the Kostolac fly ash used in the concrete. Superplasticizer based on modified polycarboxylates was added to all the concretes except for the reference concrete. 


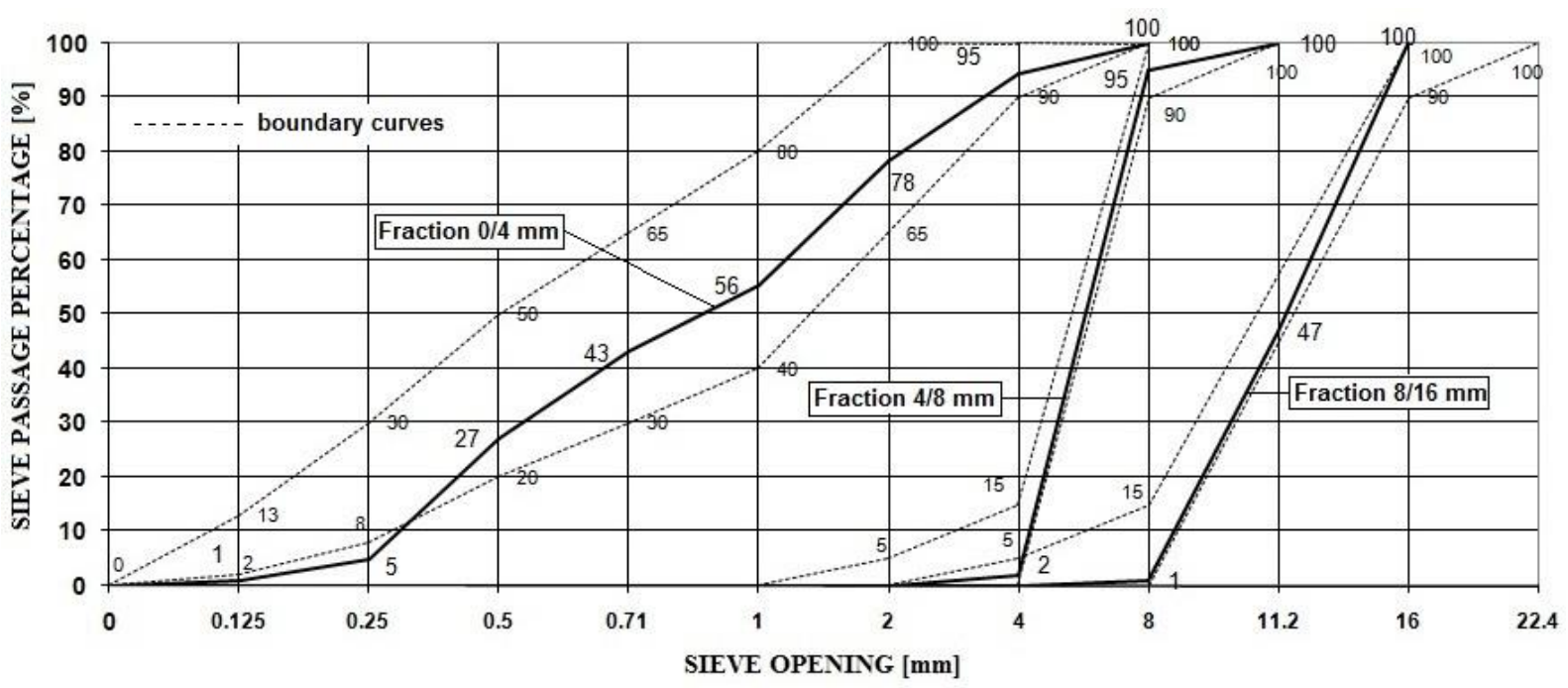

Figure 1 Particle-size distributions of the fractions

Table 1 Physical and mechanical properties of the employed cement

\begin{tabular}{lc}
\hline Property of cement & Value \\
\hline Stetting time [min] & start 135; end 160 \\
Mill fineness - sieve residue $0.09 \mathrm{~mm}$ & $3.2 \%$ \\
Density & $3000 \mathrm{~kg} / \mathrm{m}^{3}$ \\
Loose material bulk density & $925 \mathrm{~kg} / \mathrm{m}^{3}$ \\
Compacted material bulk density & $1521 \mathrm{~kg} / \mathrm{m}^{3}$ \\
Bending strength after 2 days & $5.99 \mathrm{~N} / \mathrm{mm}^{2}$ \\
Bending strength after 28 days & $7.21 \mathrm{~N} / \mathrm{mm}^{2}$ \\
Compressive strength after 2 days & $33.67 \mathrm{~N} / \mathrm{mm}^{2}$ \\
Compressive strength after 28 days & $54.21 \mathrm{~N} / \mathrm{mm}^{2}$ \\
\hline
\end{tabular}

Table 2 Chemical composition of the employed fly ash

\begin{tabular}{ccccccccccc}
\hline $\mathrm{SiO}_{2}$ & $\begin{array}{c}\mathrm{Fe}_{2} \mathrm{O}_{3} \\
{[\%]}\end{array}$ & $\begin{array}{c}\mathrm{Al}_{2} \mathrm{O}_{3} \\
{[\%]}\end{array}$ & $\begin{array}{c}\mathrm{CaO} \\
{[\%]}\end{array}$ & $\begin{array}{c}\mathrm{MgO} \\
{[\%]}\end{array}$ & $\begin{array}{c}\mathrm{SO}_{3} \\
{[\%]}\end{array}$ & $\begin{array}{c}\mathrm{P}_{2} \mathrm{O}_{5} \\
{[\%]}\end{array}$ & $\begin{array}{c}\mathrm{TiO}_{2} \\
{[\%]}\end{array}$ & $\begin{array}{c}\mathrm{N}_{2} \mathrm{O} \\
{[\%]}\end{array}$ & $\begin{array}{c}\mathrm{K}_{2} \mathrm{O} \\
{[\%]}\end{array}$ & $\begin{array}{c}\text { Loss on ignition } \\
{[\%]}\end{array}$ \\
\hline 51.68 & 11.58 & 20.16 & 7.43 & 2.41 & 1.02 & 0.12 & 1.04 & 0.88 & 1.04 & 2.57 \\
\hline
\end{tabular}

Five mixtures of fresh and hardened concrete were made in order to test their properties. The reference mixture (marked "E") was made from river aggregate, cement, water, and water reducer. Four mixtures were made in which fly ash was substituted for cement in various mass proportions. The mixture marked F15 was made with $15 \%$ fly ash substituted for cement, F20 with $20 \%$, F25 with $25 \%$, and F30 with $30 \%$. In mixing the concrete, we did not consider the concept of k-values for fly ash according to the EN 206:2013 standard; rather, we simply substituted a mass proportion of fly ash for cement. All the mixtures had the same water/cement ratio $\left(\omega_{\mathrm{c}}=0.45\right)$ and approximately the same concrete consistency (slump 90-110 mm), which was achieved using superplasticizer. Table 3 gives the compositions of the concrete mixtures.

Table 3 Compositions of concrete mixtures (volume of $1 \mathrm{~m}^{3}$ )

\begin{tabular}{|c|c|c|c|c|c|c|c|c|c|c|}
\hline \multirow{3}{*}{$\begin{array}{l}\text { Specimen } \\
\text { name }\end{array}$} & \multicolumn{6}{|c|}{ Aggregate } & \multirow{3}{*}{$\begin{array}{r}\text { Fly ash } \\
\mathrm{kg} / \mathrm{m}^{3}\end{array}$} & \multirow{3}{*}{$\begin{array}{c}\text { Cement } \\
\mathrm{kg} / \mathrm{m}^{3}\end{array}$} & \multirow{3}{*}{$\begin{array}{l}\text { Water } \\
\mathrm{kg} / \mathrm{m}^{3}\end{array}$} & \multirow{3}{*}{$\begin{array}{c}\text { Super- } \\
\text { plasticizer } \\
\mathrm{kg} / \mathrm{m}^{3}\end{array}$} \\
\hline & \multicolumn{2}{|c|}{$0 / 4 \mathrm{~mm}$} & \multicolumn{2}{|c|}{$4 / 8 \mathrm{~mm}$} & \multicolumn{2}{|c|}{$8 / 16 \mathrm{~mm}$} & & & & \\
\hline & $\%$ & $\mathrm{~kg} / \mathrm{m}^{3}$ & $\%$ & $\mathrm{~kg} / \mathrm{m}^{3}$ & $\%$ & $\mathrm{~kg} / \mathrm{m}^{3}$ & & & & \\
\hline$E$ & 45 & 795 & 25 & 445 & 30 & 530 & - & 400 & 180 & - \\
\hline F15 & 45 & 787 & 25 & 440 & 30 & 524 & 59 & 336 & 178 & 3.56 \\
\hline F20 & 45 & 778 & 25 & 436 & 30 & 519 & 78 & 313 & 176 & 3.91 \\
\hline F25 & 45 & 766 & 25 & 429 & 30 & 511 & 96 & 289 & 173 & 4.24 \\
\hline F30 & 45 & 756 & 25 & 423 & 30 & 504 & 114 & 266 & 171 & 4.56 \\
\hline
\end{tabular}


We measured the consistency of the fresh concrete by the slump test according to SRPS EN 12350-2:2010 [12], and measured the bulk density according to SRPS EN 12350-6:2010 [13]. The compressive strength and bulk density of the hardened concrete were measured using cube samples (sides of $150 \mathrm{~mm}$ ) according to SRPS ISO 4012:2000 [14], and the flexural strength was tested using prism samples (dimensions of $100 \times 100 \times 400 \mathrm{~mm}$ ) according to SRPS ISO 4013:2000 [15]. The rebound number was determined with a rebound hammer according to SRPS EN 12504-2:2008 [16], and the ultrasonic pulse velocity was measured according to SRPS EN 125044:2008 [17] using cube samples (sides of $150 \mathrm{~mm}$ ). The static modulus of elasticity was determined according to SRPS ISO 6784:2000 [18] on cylindrical cores (dimensions of $\sim 150 \times 300 \mathrm{~mm}$ ). The tested concretes all had ages of 28 days.

Figure 2 shows a schematic of the equipment used to test the concretes' abrasive resistance [19]. Similar equipment has been used by others to test the hydro-abrasive resistance of concrete [20,21].
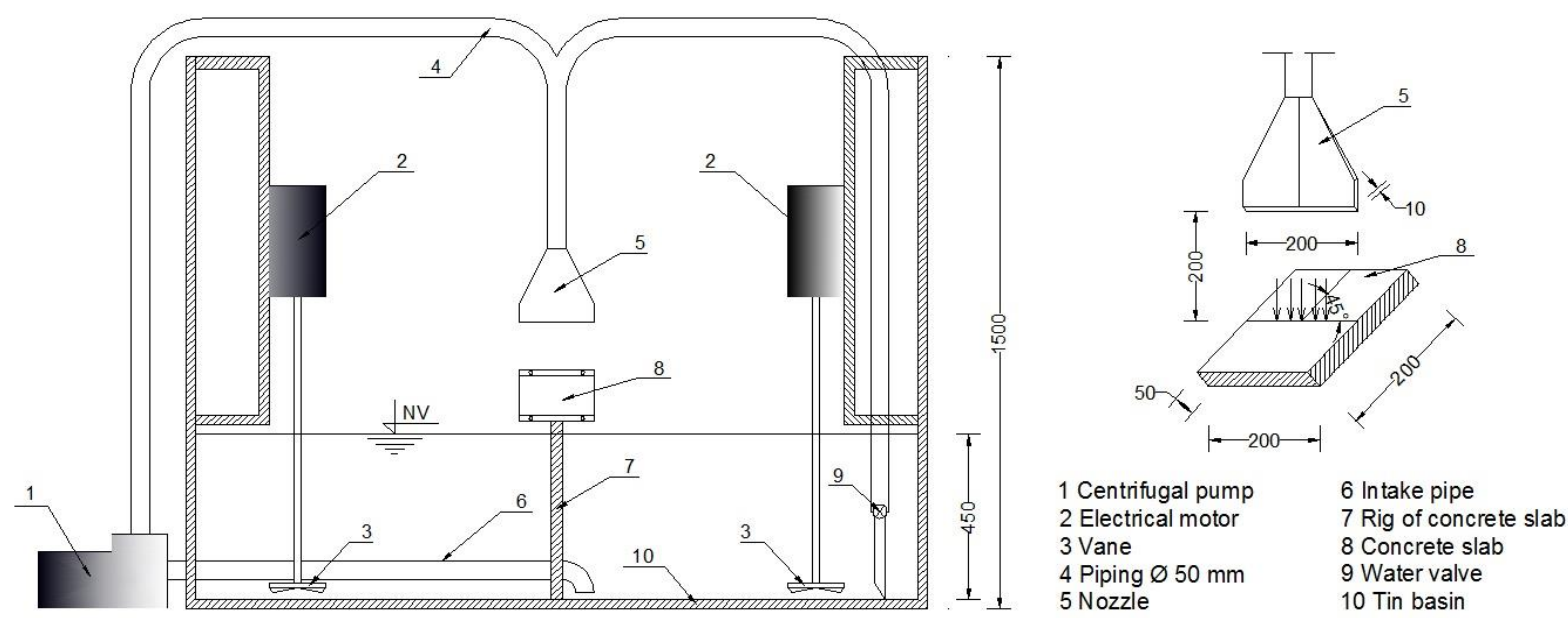

Figure 2 Equipment used to test the hydro-abrasive resistance of concrete [19]

The equipment consisted of a tin basin (base of $2.0 \times 2.0 \mathrm{~m}$, height of $1.5 \mathrm{~m}$ ), whose front side was covered with a Plexiglas panel so the tests could be observed. For the test, the basin was filled to one third of its height with the mixture of water and silica sand, with granulations from $0.6-1.2 \mathrm{~mm}$, at a mass ratio of 10:1. Four electrical motors turned vanes, making the water and sand into a homogenous mixture, while a centrifugal pump sucked the mixture through an intake and then ejected it under pressure though a nozzle at the test concrete slab (dimensions of $200 \times 200 \times 50 \mathrm{~mm}$ ). The concrete slab was fitted onto the rig, which can rotate around the horizontal axis, changing the incidence angle of the jet and the examined specimen.

The test concrete slab was dried at $105 \pm 5^{\circ} \mathrm{C}$ until its mass held constant, and then the sample mass was measured $\left(m_{1}\right)$. Then the specimen was saturated with water by gradual immersion and exposed to the action of the water/sand mixture jet for $120 \mathrm{~m}$. In this test, the water temperature was $30^{\circ} \mathrm{C}$. After this test, the specimen was again dried to constant mass, which was measured $\left(m_{2}\right)$. These measurements of specimen mass had an accuracy of $\pm 0.1 \mathrm{~g}$. The water/sand mixture was propelled at $45^{\circ}$ to the concrete test slab through a rectangular jet nozzle (dimensions of $10 \times 200 \mathrm{~mm}$ ). The nozzle jet velocity was $20 \mathrm{~m} / \mathrm{s}$, which produces a pressure of $2.4 \mathrm{bar}$ $(0.24 \mathrm{MPa})$. The difference in mass $\Delta m$ is the mass of the material abraded under the action of the abrasive suspended in water.

The hydro-abrasive mass-erosion rate $E_{R, m}$ is calculated as:

$$
E_{R, m}=\frac{\Delta m}{t}=\frac{m_{1}-m_{2}}{t}[\mathrm{~g} / \mathrm{min}]
$$

where $m_{1}$ and $m_{2}$ are the masses of the specimen, dried to constant mass, before and after being abraded with the water/abrasive mixture, and $t$ is the time that the abrasive jet mixture acted on the test sample ( $t=120 \mathrm{~min})$.

However, because the samples with different proportions of substituted fly ash have different densities, it is better to use the loss of sample volume caused by abrasive action for comparison, which is calculated as follows: 


$$
\Delta V=\frac{\Delta m}{\gamma_{\text {hard,conc }}}\left[\mathrm{cm}^{3}\right]
$$

That is, the hydro-abrasion rate by volume:

$$
\begin{aligned}
& E_{R, V}=\frac{\Delta V}{t}=\frac{\frac{m_{1}-m_{2}}{\gamma_{\text {hard,conc }}}}{t}\left[\mathrm{~cm}^{3} / \mathrm{min}\right] \\
& \text { where } \gamma_{\text {hard,conc }} \text { is the density }\left(\mathrm{g} / \mathrm{cm}^{3}\right) \text { of the hardened concrete dried to constant mass. }
\end{aligned}
$$

\section{RESULTS}

Tables 4, 5, and 6 give the measured results of fresh and hardened concrete.

Table 4 Characteristics of fresh concrete

\begin{tabular}{cccc}
\hline $\begin{array}{c}\text { Specimen } \\
\text { name }\end{array}$ & $\begin{array}{c}\text { Density } \\
{\left[\mathrm{kg} / \mathrm{m}^{3}\right]}\end{array}$ & Slump class & $\begin{array}{c}\text { Air content } \\
{[\%]}\end{array}$ \\
\hline $\mathrm{E}$ & 2350 & $\mathrm{~S} 3(110 \mathrm{~mm})$ & 3.1 \\
$\mathrm{~F} 15$ & 2325 & $\mathrm{~S} 3(100 \mathrm{~mm})$ & 4.5 \\
F20 & 2300 & $\mathrm{~S} 2(90 \mathrm{~mm})$ & 3.8 \\
F25 & 2265 & $\mathrm{~S} 3(105 \mathrm{~mm})$ & 3.0 \\
F30 & 2235 & $\mathrm{~S} 3(100 \mathrm{~mm})$ & 2.6 \\
\hline
\end{tabular}

\begin{tabular}{|c|c|c|c|c|c|}
\hline $\begin{array}{l}\text { Specimen } \\
\text { name }\end{array}$ & $\begin{array}{l}\text { Mass loss } \\
\Delta m[g]\end{array}$ & $\begin{array}{c}E_{R, m} \\
{[\mathrm{~g} / \mathrm{min}]}\end{array}$ & $\begin{array}{l}\text { Density of hardened } \\
\text { concrete dried to } \\
\text { constant mass }\left[\mathrm{g} / \mathrm{cm}^{3}\right]\end{array}$ & $\begin{array}{c}\text { Volume loss } \Delta V \\
{\left[\mathrm{~cm}^{3}\right]}\end{array}$ & $\begin{array}{c}E_{R, V} \\
{\left[\mathrm{~cm}^{3} / \mathrm{min}\right]}\end{array}$ \\
\hline$E$ & 41.4 & 0.3450 & 2.320 & 17.84 & 0.1487 \\
\hline F15 & 44.1 & 0.3675 & 2.290 & 19.26 & 0.1605 \\
\hline F20 & 53.7 & 0.4475 & 2.260 & 23.76 & 0.1980 \\
\hline $\mathrm{F} 25$ & 57.3 & 0.4775 & 2.225 & 25.75 & 0.2146 \\
\hline F30 & 66.9 & 0.5575 & 2.200 & 30.41 & 0.2534 \\
\hline
\end{tabular}

Table 5 Characteristics of hardened concrete

\begin{tabular}{ccccccc}
\hline $\begin{array}{c}\text { Specimen } \\
\text { name }\end{array}$ & $\begin{array}{c}\text { Density } \\
{\left[\mathbf{k g} / \mathbf{m}^{3}\right]}\end{array}$ & $\begin{array}{c}\text { Compressive } \\
\text { strength } \\
{[\mathrm{MPa}]}\end{array}$ & $\begin{array}{c}\text { Flexural } \\
\text { strength } \\
{[\mathrm{MPa}]}\end{array}$ & $\begin{array}{c}\text { Rebound } \\
\text { number }\end{array}$ & $\begin{array}{c}\text { Ultrasonic } \\
\text { pulse velocity } \\
{[\mathrm{m} / \mathbf{s}]}\end{array}$ & $\begin{array}{c}\text { Static modulus } \\
\text { of elasticity } \\
\text { Es [GPa] }\end{array}$ \\
\hline E & 2347 & 62.89 & 6.48 & 48.23 & 4733 & 32.0 \\
F15 & 2320 & 54.22 & 5.42 & 44.61 & 4557 & 30.4 \\
F20 & 2291 & 52.67 & 4.94 & 42.50 & 4518 & 28.8 \\
F25 & 2257 & 49.67 & 4.72 & 40.36 & 4460 & 26.7 \\
F30 & 2227 & 38.33 & 4.32 & 38.58 & 4376 & 24.9 \\
\hline
\end{tabular}

Table 6 Loss of specimen mass and volume and the abrasion erosion rate

\section{DISCUSSION AND CONCLUSION}

From the results in the previous chapter, we conclude that substituting fly ash for Portland cement in concrete greatly changes its performance, both in its fresh and hardened state. In fresh concrete, as the fly ash content increased, its density decreased by $25-115 \mathrm{~kg} / \mathrm{m}^{3}$. Also, as the fly ash content increased, the slump started to decrease, so it was corrected by adding superplasticizer in order to maintain the consistency of 90-110 mm.

In hardened concrete, its density decreased with increasing fly ash content on the same order as in the fresh concrete. Its compressive and flexural strength decreased greatly as the fly ash content increased, as 
shown in Figure 3. Comparing compressive strength, the 28-day-old samples made with $15 \%$ fly ash had $14 \%$ lower strength than the reference concrete, while the 28 -day-old samples made with $20 \%, 25 \%$, and $30 \%$ fly ash had compressive strengths $16 \%, 21 \%$ and $39 \%$ lower. Comparing flexural strength, the 28 -day-old samples made with $15 \%, 20 \%, 25 \%$, and $30 \%$ of fly ash compared to the reference concrete were $16 \%, 24 \%, 27 \%$, and $33 \%$ lower, respectively. However, note that the compressive and flexural strengths of the concretes made with fly ash increased more slowly than those of the reference concrete, so we expect a smaller difference in strength of these concretes at a high concrete age.
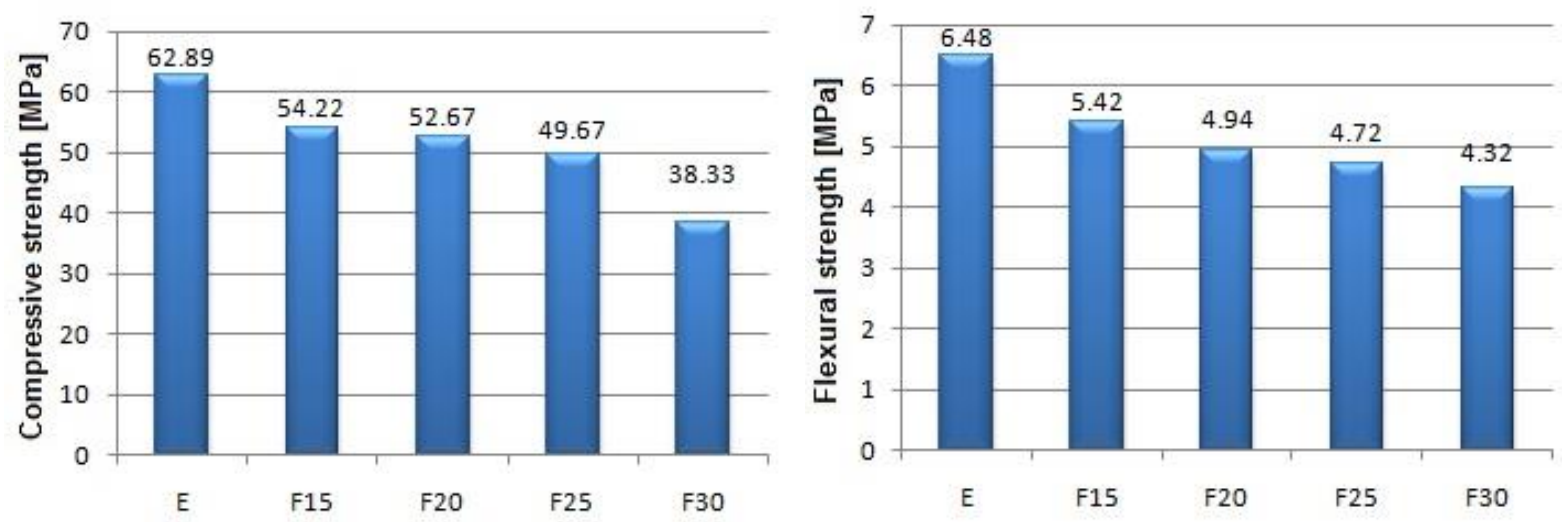

Figure 3 Compressive strength (left) and flexural strength (right) of various concretes

By propagating ultrasonic waves through the concrete samples, we found that wave velocity decreased as the fly ash content in the concrete increased, as shown in the left panel of Figure 4 . In concrete with $15 \%$ fly ash, the wave velocity decreased by $3.7 \%$ compared to the reference concrete, while in concretes with $20 \%, 25$, and $30 \%$ fly ash, it decreased by $4.5 \%, 5.8 \%$, and $7.5 \%$, respectively. The reduction in propagation speed was caused by the decrease in the concrete's density, itself caused by the increase in fly ash content.
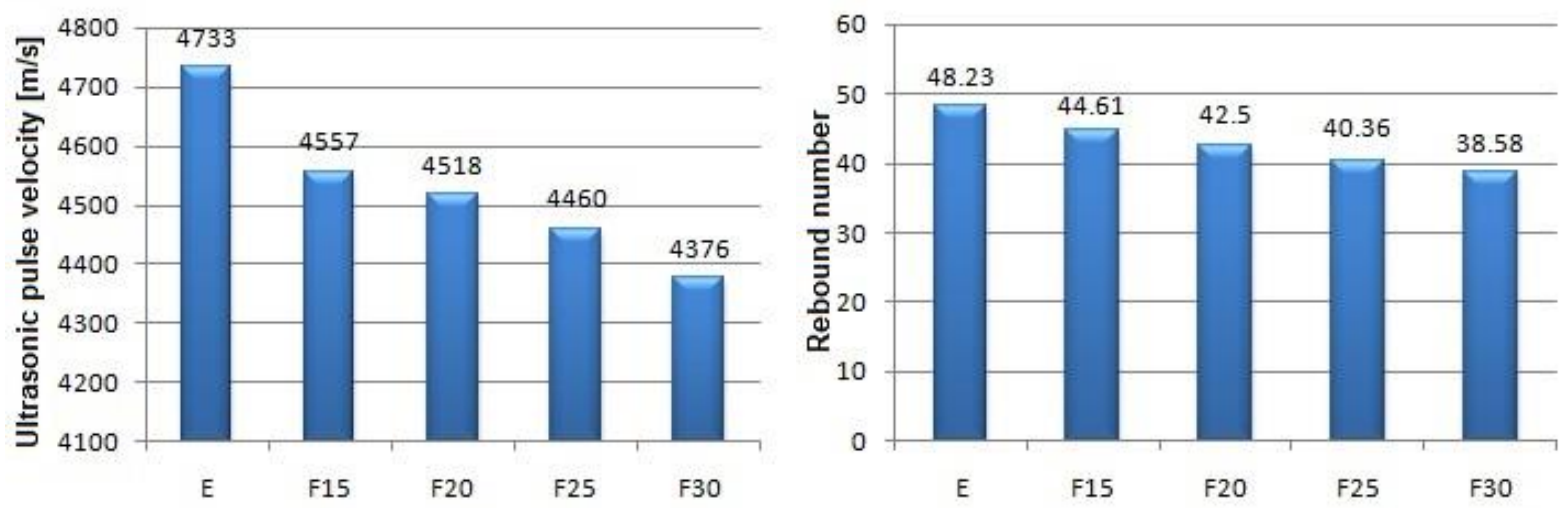

Figure 4 Ultrasonic pulse velocity (left) and rebound number (right) in various concretes

The surface hardness test by the rebound hammer tests (Figure 4, right panel) produced results similar to those from the previous tests. As the fly ash content increased, the rebound decreased. The sclerometer rebound number of concretes produced with $15 \%, 20 \%, 25 \%$, and $30 \%$ fly ash decreased by $7.5 \%, 11.9 \%, 16.3 \%$, and $20.0 \%$, respectively, compared to the reference concrete. Increasing the fly ash content reduced the compressive strength, reflected in the decrease of surface hardness.

Additionally, the static modulus of elasticity decreased with increasing fly ash content. The concrete with $15 \%$ fly ash had a static modulus $5.0 \%$ lower than the reference concrete, while the concretes with $20 \%, 25 \%$, and $30 \%$ fly ash had a $10.0 \%, 16.6 \%$, and $22.2 \%$ lower static modulus, respectively.

Figure 5 shows an analysis of the abrasion-erosion rate by volume, revealing that the concrete with $15 \%$ fly ash showed similar behavior to the reference concrete, even though the concrete with fly ash had lower 
compressive and flexural strength. As the fly ash content increased, the abrasion erosion rate by volume increased; that is, the hydro-abrasive resistance of concrete decreased. This decrease of hydro-abrasion resistance in concrete with fly ash occurred partially because it contained less aggregate compared to the reference concrete, as shown in Table 3.
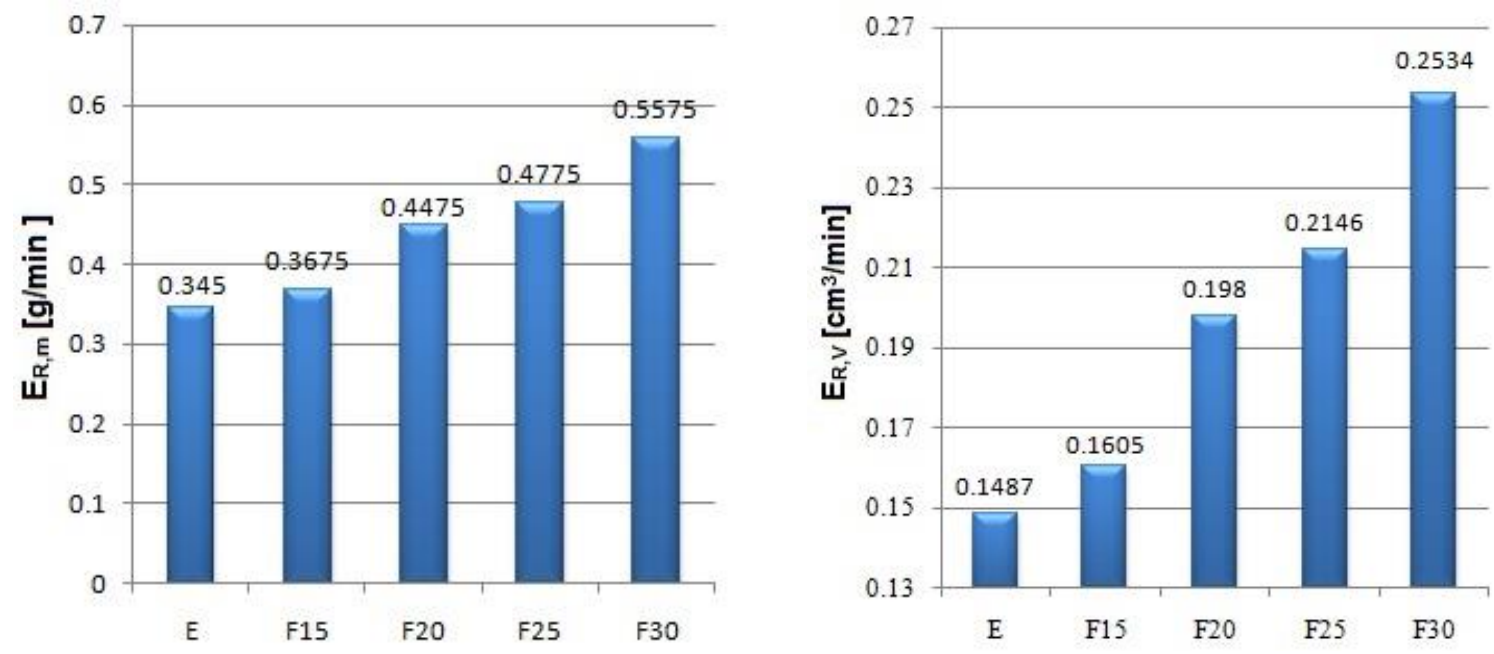

Figure 5 Abrasion erosion rates by mass (left) and by volume (right) in various concretes

Generally, the test procedure and equipment presented here are suitable and practical for measuring abrasive resistance in concrete subjected to abrasive particles and a water jet. Concrete with up to $15 \%$ fly ash substituted for cement had acceptable abrasion-erosion resistance for structural applications. Further research on designing and testing high-strength concrete should investigate higher proportions of fly ash.

\section{ACKNOWLEDGEMENTS}

This work is a part of investigation within the research project TR 36017 "Utilization of by-products and recycled waste materials in concrete composites in the scope of sustainable construction development in Serbia: investigation and environmental assessment of possible applications" supported by the Ministry for Science and Technology, Republic of Serbia. We gratefully acknowledge this support.

\section{References}

[1] Helmuth, R. 1987: Fly Ash in Cement and Concrete, Portland Cement Association R\&D Laboratories In Skokie, Illinois, ISBN 0-89312-085-5, p. 203.

[2] Brzaković, P. 2000: Priručnik za proizvodnju i primenu građevinskih materijala nemetalnog porekla., knjiga1, Orion Art, Beograd.

[3] Graham, J. R. 1998: Erosion of concrete in hydraulic structure, Reported by $\mathrm{ACl}$ Committee 210, ACl manual practice, Part I.

[4] Liu T. C. 1981: Abrasion resistance of concrete, ACl J. Proc., 78(5), pp. 341-350.

[5] Tikalsky P. J.; Carrasquillo P. M.; Carrasquillo R. L. 1988: Strength and durability considerations affecting mix proportions of concrete containing fly ash, $\mathrm{ACl}$ Materials Journal, 85(6), pp. 505-511.

[6] Langan B. W.; Joshi R. C.; Ward W. A. 1990: Strength and durability of concrete containing 50 percent Portland cement replacement by fly ash and other materials, Canadian Journal of Civil Engineering, 17, pp. 19-27. http://dx.doi.org/10.1139/190-004

[7] Dhir R. K.; Hewlett P. C.; Chan Y. N. 1991: Near-surface characteristics of concrete: abrasion resistance, Materials and Structures, 24, pp. 122-128. http://dx.doi.org/10.1007/BF02472473

[8] Siddique R. 2003: Effect of fine aggregate replacement with Class F fly ash on the abrasion resistance of concrete, Cement and Concrete Research., 33, pp.1877-1881. doi:10.1016/S0008-8846(03)00212-6 
[9] Bilodeau A.; Malhotra V. M. 1992: Concrete incorporating high volumes of ASTM class F fly ashes: mechanical properties and resistance to deicing salt scaling and to chloride-ion penetration, $\mathrm{ACl}$ Special Publication ACI SP - 132, American Concrete Institute, pp. 319-349.

[10] Yazici S.; Inan G. 2006: An investigation on the wear resistance of high strength concretes, Wear, 260, pp. 615-618. doi:10.1016/j.wear.2005.03.028

[11] Siddique R.; Khatib J. M. 2010: Abrasion resistance and mechanical properties of high-volume fly ash concrete, Materials and Structures, 43, pp. 709-718. http://dx.doi.org/10.1617/s11527-009-9523-x

[12] SRPS EN 12350-2:2010: Testing fresh concrete - Part 2: Slump-test.

[13] SRPS EN 12350-6:2010: Testing fresh concrete - Part 6: Density.

[14] SRPS ISO 4012:2000: Concrete - Determination of compressive strength of test specimens.

[15] SRPS ISO 4013:2000: Concrete - Determination of flexural strength of test specimens.

[16] SRPS EN 12504-2:2008: Testing concrete in structures - Part 2: Non-destructive testing - Determination of rebound number.

[17] SRPS EN 12504-4:2008: Testing concrete - Part 4: Determination of ultrasonic pulse velocity.

[18] SRPS ISO 6784:2000: Concrete - Determination of static modulus of elasticity in compression.

[19] Grdic Z.; Curcic G. T.; Ristic N.; Despotovic I. 2012: Abrasion resistance of concrete micro-reinforced with polypropylene fibers, Construction and Building Material, 27, pp. 305-312. doi:10.1016/..conbuildmat.2011.07.044

[20] Lui Y. W. 2007: Improving the abrasion resistance of hydraulic-concrete containing surface crack by adding silica fume, Construction and Building Material, 21, pp. 972-977.

[21] Lui Y. W; Yen T.; Hsu T. H. 2006: Abrasion erosion of concrete by water-borne sand, Cement and Concrete Research, 36, pp. 1814-1820. doi:10.1016/i.cemconres.2005.03.018 